\title{
Recent advances in the identification of hepatitis viruses*
}

\author{
Jules L. Dienstag \\ M.D. \\ Robert H. PURCELL
M.D. \\ Laboratory of Infectious Diseases, National Institute of Allergy and Infectious Diseases, \\ National Institutes of Health, Bethesda, Maryland 20014, U.S.A.
}

\begin{abstract}
Summary
Resulting directly from the discovery of virus-related antigens, rapid progress has marked the last decade of viral hepatitis research. The hepatitis $B$ virion has been tentatively identified as a DNA virus with an endogenous DNA polymerase, and new serological markers for type B hepatitis have been discovered. Hepatitis $A$ antigen has been identified on a virus-like particle thought to be the hepatitis A virion. Progressively more sophisticated assays for hepatitis antigens and antibodies have been applied to the study of viral hepatitis epidemiology and biochemicalbiophysical characterization of the agents. Most recently, knowledge learned from such studies has been exploited to develop a prototype non-infectious but immunogenic hepatitis B vaccine using hepatitis B surface antigen $\left(\mathrm{HB}_{\mathrm{s}} \mathrm{Ag}\right)$ purified in large quantities from chronic $\mathrm{HB}_{\mathrm{s}} \mathrm{Ag}$ carriers. Especially exciting is the prospect, suggested by serological studies of viral hepatitis, that hepatitis viruses besides hepatitis $A$ and $B$ viruses will be identified.
\end{abstract}

\section{Introduction}

Although hepatitis has been recognized clinically for centuries and epidemics of hepatitis have been considered viral in origin for decades, and despite recent advances in tissue culture techniques, hepatitis viruses have not been cultivated in vitro or positively identified. Within the last 6 years, however, virus-like structures associated with type B (Dane, Cameron and Briggs, 1970) and type A (Feinstone, Kapikian and Purcell, 1973) hepatitis have been found, and evidence supporting their aetiological roles is accumulating. Little more than a decade has elapsed since the serendipitous discovery of Australia antigen (Blumberg, Alter and Visnich, 1965 ) and its ultimate association with type B viral

*This work was presented in part at the Congress on Advances in Hepatology, 1976, Boario Terme, Italy, 28 March, 1976.

Correspondence: Dr J. L. Dienstag, Gastrointestinal Unit, Massachusetts General Hospital, Boston, Massachusetts 02114, U.S.A. hepatitis (Prince, 1968; Blumberg et al., 1967). The study of Australia antigen, other antigens associated with hepatitis B virus (HBV) infection, and the immune response to these antigens has provided an ever expanding understanding of the disease and its aetiological agents. Now a similar series of new insights about type A hepatitis has begun.

\section{Viral hepatitis, type B}

\section{Hepatitis $B$ surface antigen}

Based on electron microscopic studies, hepatitis B surface antigen $\left(\mathrm{HB}_{\mathrm{s}} \mathrm{Ag}\right)$ represents a specificity on three morphologically distinct forms: spherical particles approximately $22 \mathrm{~nm}$ in diameter, tubules of similar diameter and of variable length (Bayer, $?$ Blumberg and Werner, 1968), and a 42-nm doubleshelled structure, the Dane particle (Dane et al., 1970), which is thought to represent the hepatitis B virion (Fig. 1). The outer coat of the Dane particle measures $7 \mathrm{~nm}$ in width and is antigenically identical to the 22-nm spheres and tubules present in abundance and thought to represent excess viral coat material (Table 1). Residing on each $\mathrm{HB}_{\mathrm{s}} \mathrm{Ag}$ particle or component is a group-reactive determinant, $a$, and, generally, mutually exclusive allelic subdeterminants $d, y$ (Le Bouvier et al., 1972), and $w, r$ (Bancroft, Mundon and Russell, 1972), as well as numerous other recently discovered but less well characterized sub-determinants (Le Bouvier and Williams, 1975). As a result, four virus-determined major subtypes of $\mathrm{HB}_{\mathrm{s}} \mathrm{Ag}$ are recognized: $a d w$, $a y w$, $a d r$, and $a y r$. In infected liver cells, $\mathrm{HB}_{\mathrm{s}} \mathrm{Ag}$ reactivity is localized to the cytoplasm (Edgington and Ritt, 1971), and 22-nm spheres can be detected there by electron microscopy (Huang et al., 1974).

\section{Hepatitis $B$ core antigen}

Within the Dane particle and exposed by detergent or lipid solvent treatment is a 27-nm core (Almeida, Rubenstein and Stott, 1971), called hepatitis B core antigen $\left(\mathrm{HB}_{\mathrm{c}} \mathrm{Ag}\right)$, which does not cross-react antigenically with $\mathrm{HB}_{\mathrm{s}} \mathrm{Ag}$ and which elicits a distinct 


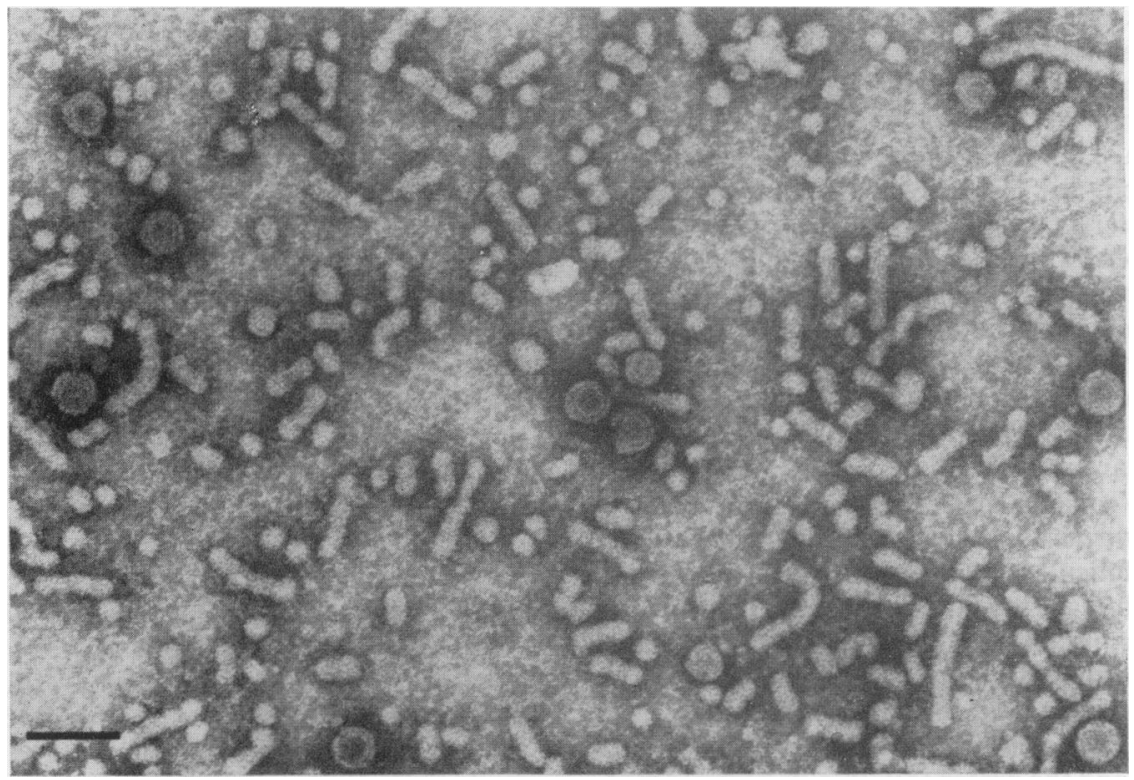

FIG. 1. Hepatitis B surface antigen components purified from the serum of a chronic carrier $(2 \%$ phosphotungstic acid negative stain). The bar represents $100 \mathrm{~nm}$.

TABLE 1. Antigens associated with hepatitis viruses

\begin{tabular}{|c|c|c|c|c|}
\hline \multirow{2}{*}{$\frac{\text { Virus }}{\text { Hepatitis B }}$} & \multirow{2}{*}{\begin{tabular}{l}
\multicolumn{1}{c}{ Antigen } \\
Hepatitis B surface \\
antigen $(\mathrm{HB} \mathrm{Ag})$
\end{tabular}} & \multicolumn{2}{|c|}{$\begin{array}{l}\text { Morphological form(s) and their presumed } \\
\text { relationship to virus }\end{array}$} & \multirow[t]{2}{*}{ Antibody } \\
\hline & & $\begin{array}{l}22 \mathrm{~nm} \text { spheres } \\
\text { Tubules of variable length } \\
\text { Coat of } 42 \mathrm{~nm} \text { Dane } \\
\text { particle }\end{array}$ & $\begin{array}{l}\text { Excess viral coat } \\
\text { material } \\
\text { Virion (surrounds } \\
\text { core) }\end{array}$ & \\
\hline & $\begin{array}{l}\text { Hepatitis B core } \\
\text { antigen }\left(\mathrm{HB}_{\mathrm{c}} \mathrm{Ag}\right)\end{array}$ & $\begin{array}{l}27 \mathrm{~nm} \text { core within Dane } \\
\text { particle }\end{array}$ & $\begin{array}{l}\text { Viral core (contains } \\
\text { DNA and DNA } \\
\text { polymerase) }\end{array}$ & Anti-HBc \\
\hline & e Antigen & None identified (soluble) & Unknown & Anti-e \\
\hline Hepatitis A & $\begin{array}{l}\text { Hepatitis A } \\
\text { antigen (HA Ag) }\end{array}$ & $27 \mathrm{~nm}$ particle & Virion & Anti-HA \\
\hline Others & None identified & None identified & & None identified \\
\hline
\end{tabular}

immune response (Hoofnagle, Gerety and Barker, 1973; Gerety, Hoofnagle and Barker, 1974; Barker et al., 1974). Staining infected liver tissue with fluorescein-labelled antibody to $\mathrm{HB}_{\mathrm{c}} \mathrm{Ag}$ (anti-HB $\mathrm{HB}_{\mathrm{c}}$ ) (Barker et al., 1973) as well as electron microscopic observation (Barker et al., 1973; Huang, 1972) localize $\mathrm{HB}_{\mathfrak{c}} \mathrm{Ag}$ to the hepatocyte nucleus (Table 1).

\section{Dane particle DNA and DNA polymerase}

Among the most exciting recent advances in the study of type B hepatitis are the localization of an HBV-specific DNA-dependent DNA polymerase (Kaplan et al., 1973; Robinson and Greenman,
1974) and a double-stranded circular DNA molecule within the core of the Dane particle (Robinson and Greenman, 1974). From Dane particles with DNA polymerase activity, double stranded circular DNA molecules have been extracted; their length corresponds to a molecular weight of $1.6 \times 10^{6}$ daltons which, theoretically, can code for about three average size proteins, and evidence suggests that these DNA molecules serve as the primer-template for synthesis of new DNA by the DNA polymerase (Robinson, Clayton and Greenman, 1974). Recently, Gerin, Ford and Purcell (1975) and Kaplan et al. (1976) described the existence of two sub-populations of 
Dane particles, one with a higher density (1.22 $\mathrm{g} / \mathrm{cm}^{3}$ in caesium chloride) which contains DNA and DNA-polymerase, and a lighter one (1.20 $\mathrm{g} / \mathrm{cm}^{3}$ ) devoid of DNA and lacking DNA polymerase. Thus, in addition to $22-\mathrm{nm}$ spheres and filaments, empty Dane particles may represent defective interfering particles which, on the one hand, compete with infectious complete virions for hepatocyte receptor sites but, on the other hand, may facilitate the establishment of a non-cytopathic persistent infection tolerated by the host (carrier state). The presence of defective interfering particles, the complexity of DNA replication imposed by the closed circular model, and the uniquely small size of the genome-smaller than the double-stranded DNA of any known virus-may explain why hepatitis B virus is so difficult to cultivate under artificial conditions. Although infectivity studies to prove the point are lacking, the candidacy of the Dane particle for the hepatitis B virion is supported by its viruslike structure including an immunologically distinct inner core, its association with a specific DNA polymerase, and the presence within its core of DNA. It is reasonable to postulate, in addition, that $\mathbf{H B}_{\mathrm{s}} \mathrm{Ag}$-positive sera with high Dane particle counts and elevated DNA polymerase activity are likely to be more infectious than $\mathrm{HB}_{\mathrm{s}} \mathrm{Ag}$-positive sera lacking these findings.

\section{Serological events during type $B$ viral hepatitis}

During acute type $B$ viral hepatitis, $\mathbf{H B}_{\mathrm{s}} \mathrm{Ag}$ appears in the blood for days to months before elevation of serum aminotransferase activity and morphological lesions in the liver. Shortly after $\mathrm{HB}_{\mathrm{s}}$ antigenaemia begins, DNA polymerase can be detected transiently (Krugman et al., 1974; Kaplan, Gerin and Alter, 1974); at approximately the same time, anti-HB $\mathrm{B}_{\mathrm{c}}$ appears and often coincides with biochemical and clinical evidence of acute hepatitis (Hoofnagle et al., 1973; Hoofnagle, Gerety and Barker, 1975). Usually not until $\mathrm{HB}_{\mathrm{s}} \mathrm{Ag}$ disappears

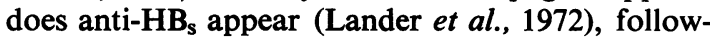
ing which it can be detected by sensitive assays for years after illness. Thus, during acute type B hepatitis, a brief interval may exist between the disappearance of $\mathrm{HB}_{s} \mathrm{Ag}$ and the appearance of anti$\mathrm{HB}_{\mathrm{s}}$ during which anti- $\mathrm{HB}_{\mathrm{c}}$ is the only indicator of HBV infection (Hoofnagle et al., 1975) (Fig. 2).

The degree and duration of each of these serological findings may vary among acutely affected individuals, and the course of events differs considerably among chronic $\mathbf{H B}_{\mathbf{s}} \mathrm{Ag}$ carriers. Since $\mathbf{H B}_{\mathbf{s}} \mathbf{A g}$ persists in the blood, no anti-HB $\mathrm{B}_{\mathrm{s}}$ is detected. Furthermore, persistence of elevated DNA polymerase activity and rising titres of anti- $\mathrm{HB}_{\mathrm{c}}$ (Hoofnagle et al., 1975) reflect continuous virus replication. Theoretically, a chronic HBV carrier with levels of $\mathrm{HB}_{\mathrm{s}} \mathrm{Ag}$ too low to detect even with sensitive test procedures may be discovered by testing for anti$\mathrm{HB}_{\mathrm{c}}$; however, in practice, this has not been verified

\section{e Antigen}

The most recently popularized addition to our ever growing awareness of the complexity of $\mathrm{HBV}$ is the ' $\mathrm{e}$ ' antigen system (Magnius and Espmark, 1972a, b). Unlike $\mathrm{HB}_{\mathrm{s}} \mathrm{Ag}$, e is a soluble protein and

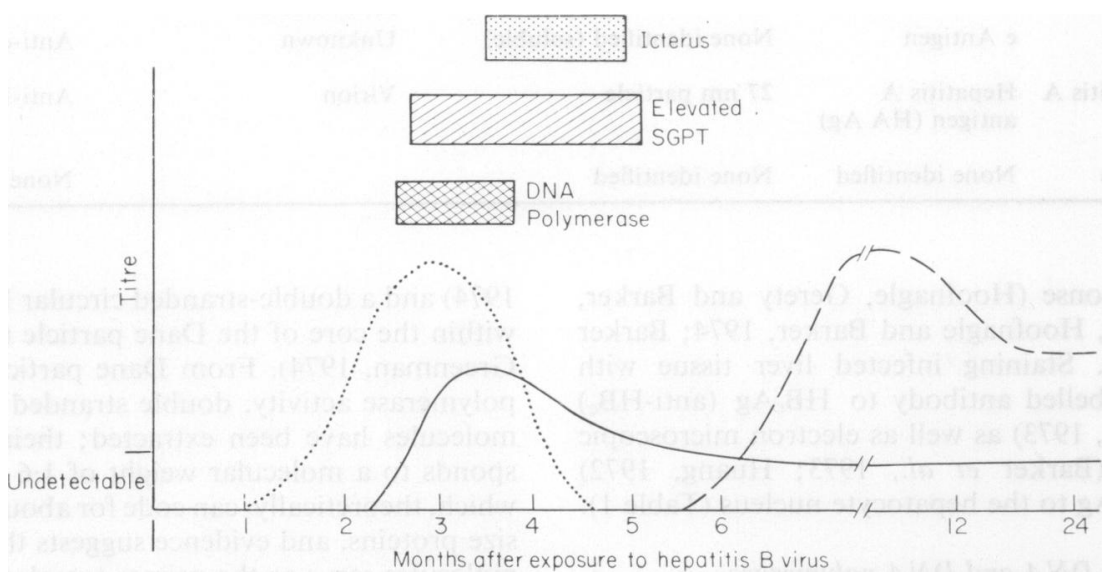

FIG. 2. Idealized representation of serological events in a typical case of acute hepatitis $B$ virus infection. Hepatitis B surface antigen $\left(\mathrm{HB}_{\mathbf{s}} \mathrm{Ag}, \ldots.\right)$, antibody to $\mathrm{HB}_{\mathbf{S}} \mathrm{Ag}$ (anti-HB $\left.\mathrm{H}_{\mathbf{s}},---\right)$, antibody to hepatitis $B$ core antigen $($ anti-HBc, - ), serum glutamic pyruvate transaminase or alanine aminotransferase (SGPT). (Reproduced with permission of Dr P. Holland, Dr H. Alter, and W. B. Saunders Co., Medical Clinics of North America, 59, 849. 1975.) 
is antigenically distinct from $\mathrm{HB}_{\mathrm{s}} \mathrm{Ag}$ of all subtypes. These antigens (at least two, $e_{1}$ and $e_{2}$, have been identified) are found only in serum containing $\mathrm{HB}_{\mathrm{s}} \mathrm{Ag}$, do not cross-react at all with $\mathrm{HB}_{\mathrm{s}} \mathrm{Ag}$ (Magnius and Espmark, 1972a, b) or $\mathbf{H B}_{\mathrm{c}} \mathrm{Ag}$ (Takahashi et al., 1976), and appear within the first several weeks of clinically recognizable illness (Magnius et al., 1975) (Table 1). Preliminary reports associate the presence of e antigen in serum with the development and perpetuation of chronic hepatitis or cirrhosis (Nielsen, Dietrichson and Juhl, 1974), with the presence of Dane particles, DNA polymerase (El Sheikh et al., 1975; Nordenfelt and Kjellen, 1975) and relatively high infectivity of $\mathrm{HB}_{\mathrm{s}} \mathrm{Ag}$ serum. Anti-e, on the other hand, appears to correlate with resolution of liver disease, better prognosis, and relatively low infectivity. Although these correlations are not absolute, studies of the properties of $e$ and its epidemiology promise to unravel still more of the mysteries of HBV.

Since, at present, there is no widely available method to abort chronic carriage of $\mathrm{HBV}$, the question of infectivity of chronic carriers has practical significance. Do we limit the activities of health care personnel who are chronic carriers? Can we determine which among them are highly infectious? Ideally, infectivity of chronic carrier serum could be tested in chimpanzees; however, the shortage of susceptible animals and the expense involved make this approach impractical. Perhaps, studies of e antigen and DNA polymerase will be useful in detecting highly infectious carriers and distinguishing them from carriers who pose less of a threat to others.

\section{Newer tests for hepatitis $B$ virus antigens and anti- bodies}

Little would have been learned about type B hepatitis without the development of ever more sophisticated serological tests for detecting its antigens and antibodies. Although a review of these procedures is beyond the present scope, several of the most reliable, sensitive, and widely used newer tests deserve mention. For the detection of $\mathbf{H B}_{\mathrm{s}} \mathbf{A g}$, radioimmunoassay techniques, with appropriate specificity testing, are the most authoritative (Ling and Overby, 1972). A less costly method, often of comparable sensitivity, immune adherence haemagglutination has been used widely in Japan to screen donor units before transfusion (Mayumi, Okochi and Nishioka, 1971).

Agar gel diffusion and counter-immunoelectrophoresis (CEP), the earliest tests used to identify $\mathrm{HB}_{\mathrm{s}} \mathrm{Ag}$ are too insensitive to detect anti-HB $\mathrm{H}_{\mathrm{s}}$ in any but the most strongly positive sera. Passive haemagglutination (Vyas and Shulman, 1970) and several modifications of radioimmunoassay, including radio- immunoprecipitation (Lander, Alter and Purcell, 1971), are very sensitive and are used currently for definitive determinations. Immune adherence haemagglutination, also useful for sensitive, practical anti-HB s testing, is being increasingly accepted (Mayumi et al., 1971).

Shortage of $\mathbf{H B}_{\mathbf{c}} \mathrm{Ag}$ precludes the commercial availability of assays to detect anti-HB $\mathrm{B}_{\mathrm{c}}$. The methods used in investigative laboratories, in ascending order of sensitivity, are complement fixation (Hoofnagle et al., 1973), CEP (Huang and Groh, 1973), immune adherence haemagglutination (Tsuda et al., 1975), and radioimmunoassay (Purcell et al., 1974; Moritsugu et al., 1975).

\section{Epidemiology}

Equipped with a vast array of test procedures for hepatitis $B$ antigens and antibodies, investigators have learned much about the transmission of type B hepatitis, as reviewed recently by Mosley (1975) and Szmuness (1975). Although parenteral inoculation with contaminated blood products is probably the most common mode of transmission, many nonpercutaneous routes have been implicated or suggested. $\mathrm{HB}_{\mathrm{S}} \mathrm{Ag}$ has been found in virtually every body secretion including saliva and semen, and several possible routes of spread have been suggested including venereal, oral, droplet, contact, arthropod-borne, and vertical transmission, in addition too overt parenteral and concealed parenteral modes of spread. Among non-percutaneous modes of transmission, oral, venereal, and vertical spread are probably the most important.

A large proportion of sporadic hepatitis unrelated to known exposure and once considered 'infectious hepatitis' can be identified as type $B$ hepatitis on the basis of tests for $\mathrm{HB}_{\mathrm{s}} \mathrm{Ag}$, anti-HB , and anti-HB $\mathrm{HB}_{\mathrm{c}}$. Exposure to hepatitis $B$ virus varies with geographical location, ethnic background and occupation, increases directly with age and inversely with rising socioeconomic class. The chronic carrier rate after infection is approximately $5-10 \%$ (Redeker, 1975). As mentioned earlier, tests for DNA polymerase activity, Dane particle numbers, e antigen and antibody may provide prognostic clues, and tests for $\mathrm{HB}_{\mathrm{s}} \mathrm{Ag}$ subtypes are useful as general epidemiological tools. In addition, serological studies have suggested, but not proved, a role for HBV in polyarteritis nodosa (Gocke et al., 1970; Sergent et al., 1976), glomerulonephritis (Brzosko et al., 1974), and hepatic cell carcinoma (Williams, 1975).

\section{Control of viral hepatitis type B}

Experimental studies in chimpanzees and epidemiological studies in man suggest that the presence of anti-HB $\mathrm{H}_{\mathrm{s}}$ correlates with immunity to $\mathrm{HBV}$ infection. Although trials of passive immunization 
with hepatitis B immune globulin have recently been reported (Iwarson et al., 1975; Couroucé-Pauty, Delons and Soulier, 1975; Desmyter et al., 1975; Seeff et al., 1975; Surgenor et al., 1975; Grady and Lee, 1975; Prince et al., 1975; Redeker et al., 1975), more promising is the progress toward development of an $\mathrm{HBV}$ vaccine for active immunization. Unique among modern viral vaccines, an HBV vaccine has been prepared without cultivating $\mathrm{HBV}$ in vitro: instead, the 22-nm spherical forms of $\mathrm{HB}_{\mathrm{s}} \mathrm{Ag}$ were purified from the plasma of chronic $\mathbf{H B}_{\mathbf{s}} \mathrm{Ag}$ carriers (Purcell and Gerin, 1975; Hilleman et al., 1975). Separated from Dane particles and tubular forms of $\mathrm{HB}_{\mathrm{s}} \mathrm{Ag}$, then inactivated with formalin, the 22-nm particle vaccine has been shown to be immunogenic but non-infectious. In a preliminary study, vaccinated chimpanzees were protected against HBV infection when challenged 24 weeks after vaccination, whereas non-vaccinated chimpanzees developed hepatitis (Purcell et al., 1975). Another approach to vaccine development, the use of polypeptides derived from $\mathrm{HB}_{\mathrm{s}} \mathrm{Ag}$, is also being investigated (Dreesman et al., 1975; Shih and Gerin, 1975). The relatively poor immunogenicity of these polypeptides and the difficulty of large scale purification may limit the applicability of this method. Currently, extensive efficacy and long-term safety tests in chimpanzees are under way for the 22-nm particle vaccine, as are detailed evaluations of the immune response-both humoral and cellular - to the new vaccine. A successful trial of the 22-nm particle vaccine in man was recently reported by Maupas et al. (1976), who inoculated patients and staff in a haemodialysis unit.

More recently Greenberg et al. (1976), Desmyter et al. (1976), and Purcell et al. (1976a) have presented data indicating that exogenously administered interferon or interferon inducers may limit HBV replication in $\mathbf{H B}_{\mathrm{s}} \mathrm{Ag}$ chronic carriers.

\section{Viral hepatitis, type A}

Although nature has bestowed upon man a hepatitis virus less virulent than type $B$, she has deprived him of an abundant type $A$ viral.antigen as a serological marker. Consequently, and because hepatitis A virus (HAV) has not been cultivated in vitro either, progress in its study lagged considerably behind. Studies in humans in the 1940s, 1950s and 1960s and experimental infection of marmosets (tamarins) in the 1960 s and early 1970s characterized HAV as a small virus resistant to ether and heat, transmissible in faeces and blood collected during the incubation period and acute illness, and immunologically distinct from HBV (Voegt, 1942; MacCallum and Bradley, 1944; Findlay and Wilcox, 1945; Paul et al., 1945; Neefe, Gellis and Stokes, 1946; Havens, 1945a, b, 1946; Krugman, Ward and Giles, 1962; Krugman, Giles and Hammond, 1967;
Mascoli et al., 1973; Provost et al., 1973). Although infectivity of blood and faeces was demonstrated in these pioneering studies, HAV was not cultivated from or identified in any of these specimens.

\section{Hepatitis $A$ antigen}

Data and clinical specimens generated in early volunteer and marmoset studies, however, were instrumental to the ultimate visualization of a viruslike particle with hepatitis $A$ antigen activity. In 1973, Feinstone et al. (1973) used immune electron microscopy to examine stool specimens taken from prison volunteers infected with the Willowbrook MS-1 strain of HAV. In these studies, Feinstone incubated convalescent serum from one of the volunteers with filtrates of acute phase stool specimens and detected aggregates and single $27-\mathrm{nm}$ viruslike particles coated with antibody (Fig. 3). The association of these particles, designated hepatitis A antigen (HA Ag), with HAV infection was supported by the failure to detect immune aggregates when preinoculation or convalescent stools were used as an antigen source or when acute phase stools were incubated wth pre-inoculation serum from patients with type A hepatitis or convalescent serum from patients with type $B$ hepatitis or viral gastroenteritis. Furthermore, serological responses to $\mathrm{HA} \mathrm{Ag}$ were demonstrated in paired serum samples of patients with experimental and natural type $\mathbf{A}$ hepatitis.

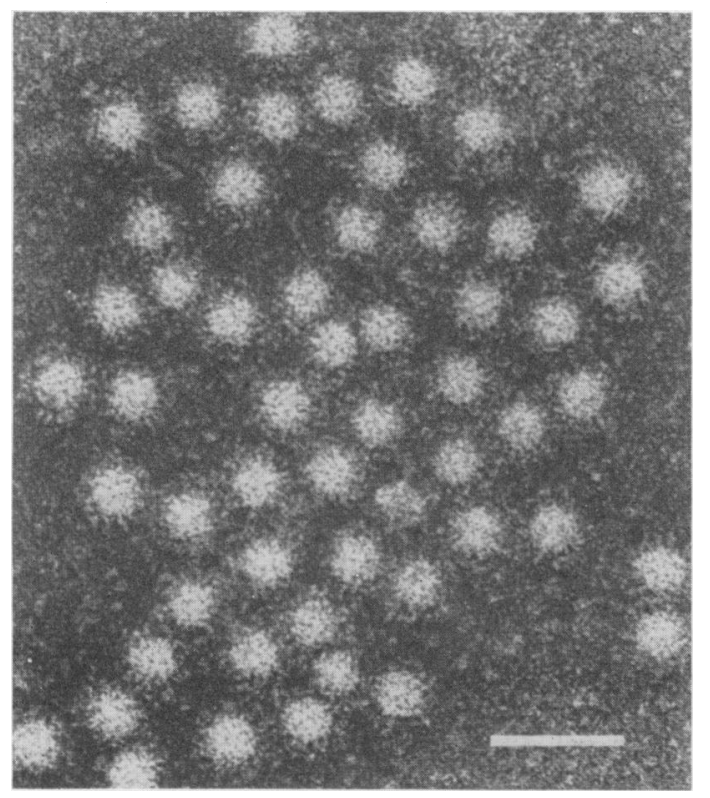

Fig. 3. Antibody-coated aggregate of hepatitis A antigen particles purified from the stools of a patient with acute type A hepatitis (2\% phosphotungstic acid negative stain). The bar represents $100 \mathrm{~nm}$. 
Reports soon followed describing studies by Provost et al. (1975b) in which similar virus-like particles were observed in the sera and livers of Sanguinus mystax (marmosets) experimentally infected with the CR326 strain of HAV, which had been extensively characterized at the Merck Institute (Mascoli et al., 1973; Provost et al., 1973). Since particles were observed by thin section electron microscopy within cytoplasmic vesicles, since buoyant density determinations and preliminary nucleic acid determinations were suggestive, Provost et al. (1975b) proposed that HAV is an RNA-containing enterovirus. The multiple densities for $\mathrm{HA} \mathrm{Ag}$ detected by others, however (Feinstone et al., 1974; Bradley et al., 1975; Moritsugu et al., 1976), and the heat stability of HAV are more characteristic of parvoviruses, small viruses containing single stranded DNA; additional characterization of $\mathrm{HAV}$ is needed before final classification of virus type can be made.

Identification of $\mathrm{HA} \mathrm{Ag}$ particles in experimental infection of man and marmoset was confirmed by the detection of antigenically and morphologically indistinguishable particles in the stools of naturally infected humans (Gravelle et al., 1975; Locarnini et al., 1974; Dienstag et al., 1975c) and in the liver, bile and stool of experimentally infected chimpanzees (Schulman et al., 1976), a species of non-human primates recently shown to be susceptible to HAV infection (Dienstag et al., 1975b). Preliminary evidence indicates that $\mathrm{HA} \mathrm{Ag}$ isolates from different geographical areas and from different sources are immunologically related, if not identical, suggesting that there is one serotype of HAV. The HA Ag particle probably is the virus of type $A$ hepatitis (Table 1).

Newer tests for hepatitis $A$ virus antigen and antibody Although immune electron microscopy is a specific, sensitive, and quantitative assay for $\mathrm{HA} \mathrm{Ag}$ and antibody to HA Ag (anti-HA), its practicality for large scale testing is limited. With HA Ag purified from marmoset livers, Provost et al. (1975a) developed a complement fixation test and Miller et al. (1975) an even more sensitive immune adherence haemagglutination (IAHA) test. Since there is a shortage of marmosets, other sources of HA Ag have been tapped and, recently, Moritsugu et al. (1976) reported the successful use of stools from humans with naturally-acquired $\mathrm{HAV}$ infection as an $\mathrm{HA} \mathrm{Ag}$ source for IAHA. Of the few techniques available today, IAHA has proved the most economical, simple, and widely used; however, it is still not commercially available. Another useful test, also limited to research laboratories, is a solid phase radioimmunoassay, which can be modified to detect both HA Ag and anti-HA (Hollinger et al., 1975; Purcell et al., 1976b).
Detectable events during type $A$ viral hepatitis

After a brief incubation period of approximately 2-4 weeks, the first detectable laboratory index of $\mathrm{HAV}$ infection is excretion of $\mathrm{HA} \mathrm{Ag}$ particles in stool. Faecal HA Ag shedding coincides with the onset of non-specific symptoms (malaise, abdominal pain, anorexia, etc.) and usually reaches a peak before significant elevation of serum aminotransferase activity and histological evidence of liver damage can be detected. Since $\mathrm{HA}$ Ag shedding occurs so early and usually disappears before jaundice becomes biochemically and clinically apparent, patients rarely have detectable $\mathrm{HA} \mathrm{Ag}$ in their stools when they present with obvious hepatitis to a physician (Dienstag et al., 1975a). As Krugman observed in studies among children at the Willowbrook State School, faeces are infectious early during incubation and not much later than the initial appearance of jaundice (Krugman et al., 1962). Antibody to HA Ag can be detected by immune electron microscopy or complement fixation during acute illness; however, the appearance of anti-HA cannot be detected for from 1 to 4 weeks after acute illness by IAHA. Subsequently anti-HA titres rise gradually and reach a peak, in man, about 2-3 months after acute illness. Although titres fall afterwards, relatively high titres may persist even 10 years after infection (Moritsugu et al., 1976; Gravelle et al., 1975; Locarnini et al., 1974; Dienstago et al., 1975c, 1975b; Provost et al., 1975a; Miller? et al., 1975; Krugman, Friedman and Lattimer, 1975; Dienstag, Alling and Purcell, 1976a) (Fig. 4).

\section{Epidemiology}

Recently available serological techniques have been applied to investigate modes of HAV transmission and prevalence of HAV infection. Serological evidence for infection with HAV has been demonstrated in common-source water-borne (Feinstone et al., 1973; Purcell et al., 1975) and foodborne outbreaks (Feinstone et al., 1973; Gravelle et al., 1975; Dienstag et al., 1975c; Purcell et al., 1975), shellfish-associated hepatitis (Dienstag et al., 1976c), intra-family and intra-institutional outbreaks (Feinstone et al., 1973; Purcell et al., 1975), and nonhuman primate-associated hepatitis (Dienstag et al., 1976b). A significant proportion of sporadic hepatitis has also been attributed serologically to HAV. On the other hand, although HAV can be transmitted experimentally by parenteral inoculation, type A hepatitis has not been confirmed serologically as a significant contribution to transfusion-associated hepatitis (Feinstone et al., 1975; Knodell et al., 1975), haemodialysis-associated hepatitis (Zuckerman, Couroucé and Szmuness, unpublished data), drug abuse-related hepatitis (Mosley et al., 1977), or other forms of percutaneous transmission via blood and 


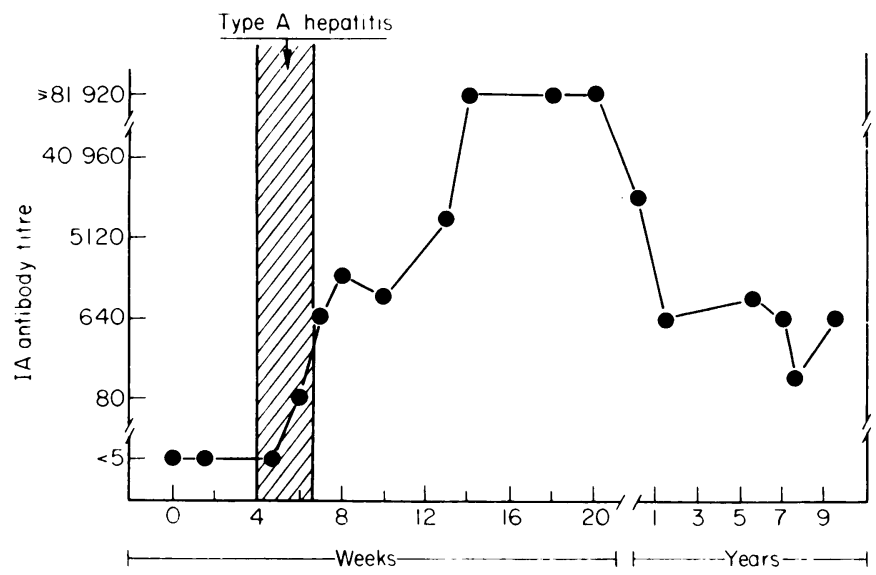

FIg. 4. Serial determinations of antibody to hepatitis A antigen by immune adherence (IA) haemagglutination in a patient with viral hepatitis, type A. (Reproduced with permission of Dr Saul Krugman and the New England Journal of Medicine, 292, 1141. 1975.)

blood products. The rarity of percutaneous spread of HAV infection is consistent with the lack of a chronic HAV carrier state.

Serological surveys have also confirmed epidemiological observations which suggest that frequency of exposure to HAV increases proportionally with age (Purcell et al., 1975; Szmuness et al., 1976; Villarejos et al., 1976) and inversely with rising socio-economic status (Miller et al., 1975; Szmuness et al., 1976; Villarejos et al., 1976).

\section{Control of viral hepatitis, type A}

Passive immunization with immune serum globulin is the only available method to prevent or modify HAV infection. Since non-infectious virus antigens have not been identified, and since HAV has not been purified in large enough quantities from clinical material, the development of a vaccine must await in vitro cultivation of $\mathrm{HAV}$.

\section{Viral hepatitis, type non-A, non-B}

The availability of sensitive serological tests for HAV and HBV made possible definitive aetiological classifications of viral hepatitis. Post-transfusion hepatitis was once considered to be exclusively type B hepatitis; however, a significant proportion of these cases have no serological evidence for HBV infection. Initially, it was thought, these patients were infected with $\mathrm{HBV}$ but serological tests were not sensitive enough to detect $\mathrm{HB}_{\mathrm{s}} \mathrm{Ag}$ or anti-HB . Today, however, sensitivity of testing procedures is adequate to make or exclude a diagnosis of type B hepatitis with almost complete confidence, if serial evaluations are performed after transfusion and throughout convalescence. Application of these sensitive tests revealed that many transfusionassociated cases were not caused by $\mathrm{HBV}$, and recent serological testing for anti-HA has failed to incriminate HAV also (Feinstone et al., 1975; Knodell et al. 1975). Cases of hepatitis which are serologically neither type A nor type B also occur among drug abusers (Mosley et al., 1977), haemodialysis patients (Zuckerman and Couroucé, unpublished data), intrafamily contacts (Villarejos et al., 1975), and intrainstitutional contacts (Ogra, unpublished data). Both cytomegalovirus and Epstein-Barr virus have also been excluded as the aetiological agent in most of these cases. Thus, the occurrence of what has been designated 'non-A, non-B' hepatitis suggests that one or more other hepatitis viruses exist. To date, however, no virus or virus antigen has been identified in these cases of human 'non-A, non-B' hepatitis.

\section{Acknowledgments}

We thank Dr Paul Holland and Dr Saul Krugman for permission to reproduce their original figures and $\mathrm{Mrs}$ Virginia Frye for preparation of the manuscript.

\section{References}

Almeida, J.D., Rubenstein, D. \& Stott, E.J. (1971) New antigen-antibody system in Australia antigen-positive hepatitis. Lancet, ii, 1225.

BANCROFt, W.H., Mundon, F.K. \& Russell, P.K. (1972) Detection of additional antigenic determinants of hepatitis B antigen. Journal of Immunology, 109, 842.

Barker, L.F., Almeida, J.D., Hoofnagle, J.H., Gerety, R.J., JaCkson, D.R. \& McGrath, P.P. (1974) Hepatitis B core antigen: immunology and electron microscopy. Journal of Virology, 14, 1552. 
Barker, L.F., Chisari, F.V., McGrath, P.P., Dalgard, D.W., Kirschstein, R.L., Almeida, J.D., Edgington, T.S., SharP, D.G. \& Peterson, M.R. (1973) Transmission of type B viral hepatitis to chimpanzees. Journal of Infectious Diseases, 127, 648.

Bayer, M.E., BlumberG, B.S. \& Werner, B.G. (1968) Particles associated with Australia antigen in the sera of patients with leukaemia, Down's syndrome and hepatitis. Nature. London, 218, 1057.

Blumberg, B.S., Alter, H.J. \& Visnich, S. (1965) A 'new' antigen in leukemia sera. Journal of the American Medical Association, 191, 541.

Blumberg, B.S., Gerstley, B.J.S., Hungerford, D.A., London, W.T. \& Sutnick, A.I. (1967) A serum antigen (Australia antigen) in Down's syndrome, leukemia, and hepatitis. Annals of Internal Medicine, 66, 924.

Bradley, D.W., Hornbeck, C.L., Gravelle, C.R., Cook, E.H. \& MAYNARD, J.E. (1975) CsCl banding of hepatitis A associated virus-like particles. Journal of Infectious Diseases, 131, 304.

Brzosko, W.J., Krawczynski, K., Nazarewicz, T., Morzycka, M. \& Nowoslawski, A. (1974) Glomerulonenephritis associated with hepatitis-B surface antigen immune complexes in children. Lancet, ii, 477.

Couroucé-Pauty, A.-M., Delons, S. \& Soulier, J.P. (1975) Attempt to prevent hepatitis by using specific anti-HBs immunoglobulin. American Journal of the Medical Sciences, 270, 375.

Dane, D.S., Cameron, C.H. \& Briggs, M. (1970) Virus-like particles in serum of patients with Australia antigenassociated hepatitis. Lancet, i, 695.

Desmyter, J., Bradburne, A.F., Vermylen, C., Daneels, R. \& BoelaerT, J. (1975) Hepatitis-B immunoglobulin in prevention of $\mathrm{HB}_{\mathrm{s}}$ antigenaemia in haemodialysis patients. Lancet, ii, 377.

Desmyter, J., Ray, M.B., De Groote, J., Bradburne, A.F., Desmet, V.J., Edy, V.G., Billiau, A., De Somer, P. \& Mortelmans, J. (1976) Administration of human fibroblast interferon in chronic hepatitis-B infection. Lancet, ii, 645.

Dienstag, J.L., Alling, D.W. \& Purcell, R.H. (1976a) Quantitation of antibody to hepatitis A antigen by immune electron microscopy. Infection and Immunity, 13, 1209.

Dienstag, J.L., Davenport, F.M., McCollum, R.W., Hennessy, A.V., Klatskin, G. \& Purcell, R.H. (1976b) Non-human primate-associated viral hepatitis type A: serologic evidence of hepatitis A virus infection. Journal of the American Medical Association, 236, 462.

Dienstag, J.L., Feinstone, S.M., Kapikian, A.Z., Purcell, R.H., Boggs, J.D. \& ConRad, M.E. (1975a) Faecal shedding of hepatitis A antigen. Lancet, i, 765.

Dienstag, J.L., Feinstone, S.M., Purcell, R.H., HoofNagle, J.H., Barker, L.F., London, W.T., Popper, H., Peterson, J.M. \& Kapikian, A.Z. (1975b) Experimental infection of chimpanzees with hepatitis A virus. Journal of Infectious Diseases, 132, 532.

Dienstag, J.L., Gust, I.D., Lucas, C.R., Wong, D.C. \& Purcell, R.H. (1976c) Mussel-associated viral hepatitis, type A: serological confirmation. Lancet, i, 561 .

Dienstag, J.L., Routenberg, J.A., Purcell, R.H., Hooper, R.R. \& HARRISON, W.O. (1975c) Foodhandler-associated outbreak of hepatitis type A: an immune electron microscopic study. Annals of Internal Medicine, 83, 647.

Dreesman, G.R., Chairez, R., Suarez, M., Hollinger, F.B., Courtney, R.J. \& Melnick, J.L. (1975) Production of antibody to individual polypeptides derived from purified hepatitis B surface antigen. Journal of Virology, 16, 508.

Edgington, T.S. \& RitT, D.J. (1971) Intrahepatic expression of serum hepatitis virus-associated antigens. Journal of Experimental Medicine, 134, 871.
El Sheikh, N., Woolf, I.L., Galbraith, R.M., Eddleston, A.L.W.F., DYmock, I.W. \& Williams, R. (1975) e Antigen-antibody system as indicator of liver damage in patients with hepatitis-B-antigen. British Medical Journal, 4, 252.

Feinstone, S.M., Kapikian, A.Z., Gerin, J.L. \& Purcell, R.H. (1974) Buoyant density of the hepatitis A virus-like particle in cesium chloride. Journal of Virology, 13, 1412.

Feinstone, S.M., Kapikian, A.Z. \& Purcell, R.H. (1973) Hepatitis A: detection by immune electron microscopy of a virus-like antigen associated with acute illness. Science, $182,1026$.

Feinstone, S.M., Kapikian, A.Z., Purcell, R.H., Alter, H.J. \& Holland, P.V. (1975) Transfusion-associated hepatitis not due to viral hepatitis type A or B. New England Journal of Medicine, 292, 767.

Findlay, G.M. \& Wilcox, R.R. (1945) Transmission of infective hepatitis by faeces and urine. Lancet, i, 212.

Gerety, R.J., Hoofnagle, J.H. \& Barker, L.F. (1974) Humoral and cell-mediated immune responses to two hepatitis $B$ virus antigens in guinea-pigs. Journal of Immunology, 113, 1223.

Gerin, J.L., Ford, E.C. \& Purcell, R.H. (1975) Biochemical characterization of Australia antigen. American Journal of Pathology, 81, 651.

Gocke, D.J., Hsu, C., Morgan, C., Bombardieri, S., Lockshin, M. \& Christian, C.L. (1970) Association between polyarteritis and Australia antigen. Lancet, ii, 1149.

Grady, G.F. \& LeE, V.A. (1975) Hepatitis B immune globulin-prevention of hepatitis from accidental exposure among medical personnel. New England Journal of Medicine, 293, 1067.

Gravelle, C.R., Hornbeck, C.L., Maynard, J.E., Schable, C.A., CoOK, E.H. \& Bradley, D.W. (1975) Hepatitis A : report of a common-source outbreak with recovery of ace possible etiologic agent. II. Laboratory studies. Journal of $\rightleftharpoons$ Infectious Diseases, 131, 167.

Greenberg, H.B., Pollard, R.B., Lutwick, L.I., Gregory, P.B., Robinson, W.S. \& Merigan, T.C. (1976) Effect of human leukocyte interferon on hepatitis B virus infection in patients with chronic active hepatitis. New England Journal of Medicine, 295, 517.

Havens, W.P., JR (1945a) Experiment in cross immunity between infectious hepatitis and homologous serum jaundice. Proceedings of the Society for Experimental Biology and Medicine, 59, 148.

Havens, W.P., JR (1945b) Properties of the etiologic agent of infectious hepatitis. Proceedings of the Society for Experimental Biology and Medicine, 58, 203.

Havens, W.P., JR (1946) Period of infectivity of patients with experimentally induced infectious hepatitis. Journal of Experimental Medicine, 83, 251.

Hilleman, M.R., Buynak, E.G., Roehm, R.R., Tytell, A.A., Bertland, A.U. \& Lampson, G.P. (1975) Purified and inactivated human hepatitis B vaccine: progress report. American Journal of the Medical Sciences, 270, 401.

Hollinger, F.B., Bradley, D.W., Maynard, J.E., DreesMAN, G.R. \& MELnick, J.L. (1975) Detection of hepatitis A viral antigen by radioimmunoassay. Journal of Immunology, 115, 1464.

Hoofnagle, J.H., Gerety, R.J. \& Barker, L.F. (1973) Antibody to hepatitis-B-virus core in man. Lancet, ii, 869.

Hoofnagle, J.H., Gerety, R.J. \& Barker, L.F. (1975) Antibody to hepatitis B core antigen. American Journal of the Medical Sciences, 270, 179.

HuANG, S.-N. (1972) Hepatitis-associated antigen hepatitis: an electron microscopic study of virus-like particles in liver cells. American Journal of Pathology, 64, 483. 
Huang, S.-N. \& Groh, V. (1973) A study on antibodies produced with liver tissue containing Australia antigen and virus-like particles. Laboratory Investigation, 29, 743.

Huang, S.-N., Groh, V., Beaudoin, J.G., Dauphinee, W.D., Guttmann, R.D., Morehouse, D.D., Aronoff, A. \& GAULT, H. (1974) A study of the relationship of virus-like particles and Australia antigen in liver. Human Pathology, 5, 209.

Iwarson, S., Kuellman, H., Ahlmén, J., Luunggren, C., Eriksson, E., Selander, D. \& Hermodsson, S. (1975) Hepatitis B immune serum globulin and standard gamma globulin in prevention of hepatitis B infection among hospital staff: a preliminary report. American Journal of the Medical Sciences, 270, 385.

Kaplan, P.M., Ford, E.C., Purcell, R.H. \& Gerin, J.L. (1976) Demonstration of subpopulations of Dane particles. Journal of Virology, 17, 885.

Kaplan, P.M., Gerin, J.L. \& Alter, H.J. (1974) Hepatitis B-specific DNA polymerase activity during post-transfusion hepatitis. Nature. London, 249, 762.

Kaplan, P.M., Greenman, R.L., Gerin, J.L., Purcell, R.H. \& RoBINSON, W.S. (1973) DNA polymerase associated with human hepatitis B antigen. Journal of Virology, 12, 995.

Knodell, R.G., Conrad, M.E., Dienstag, J.L. \& Bell, C.J. (1975) Etiological spectrum of post-transfusion hepatitis. Gastroenterology, 69, 1278.

Krugman, S., Friedman, H. \& Lattimer, C. (1975) Viral hepatitis, type A. Identification by specific complement fixation and immune adherence tests. New England Journal of Medicine, 292, 1141.

Krugman, S., Giles, J.P. \& Hammond, J. (1967) Infectious hepatitis: evidence for two distinctive clinical, epidemiological, and immunological types of infection. Journal of the American Medical Association, 200, 365.

Krugman, S., Hoofnagle, J.H., Gerety, R.J., Kaplan, P.M. \& Gerin, J.L. (1974) Viral hepatitis, type B: DNA polymerase activity and antibody to hepatitis B core antigen. New England Journal of Medicine, 290, 1331.

Krugman, S., Ward, R. \& Giles, J.P. (1962) The natural history of infectious hepatitis. American Journal of Medicine, 32, 717.

Lander, J.J., Alter, H.J. \& Purcell, R.H. (1971) Frequency of antibody to hepatitis-associated antigen as measured by a new radioimmunoassay technique. Journal of Immunology, 106, 1166.

Lander, J.J., Holland, P.V., Alter, H.J., Chanock, R.M. \& Purcell, R.H. (1972) Antibody to hepatitis-associated antigen: frequency and pattern of response as detected by radioimmunoprecipitation. Journal of the American Medical Association, 220, 1079.

Le Bouvier, G.L., McCollum, R.W., Hierholzer, W.J., JR, Irwin, G.R., Krugman, S. \& Giles, J.P. (1972) Subtypes of Australia antigen and hepatitis B virus. Journal of the American Medical Association, 222, 928.

Le Bouvier, G.L. \& Williams, A. (1975) Serotypes of hepatitis $B$ antigen $\left(\mathrm{HB}_{\mathrm{s}} \mathrm{Ag}\right)$ : the problem of 'new' determinants, as exemplified by ' $t$ '. American Journal of the Medical Sciences, 270, 165.

Ling, C.A. \& Overby, L.R. (1972) Prevalence of hepatitis B virus antigen as revealed by direct radioimmune assay with ${ }^{125}$ I-antibody. Journal of Immunology, 109, 834.

Locarnini, S.A., Ferris, A.A., Stott, A.C. \& Gust, I.D. (1974) The relationship between a $27-\mathrm{nm}$ virus-like particle and hepatitis $\mathrm{A}$ as demonstrated by immune electron microscopy. Intervirology, 4, 110.

MacCallum, F.O. \& Bradley, W.H. (1944) Transmission of infective hepatitis to human volunteers. Lancet, ii, 228.

MaGNiUS, L.O. \& EspmarK, J.A. (1972a) A new antigencomplex co-occurring with Australia antigen. Acta pathologica microbiologica scandinavica $(B), 80,335$.
Magnius, L.O. \& Espmark, J.A. (1972b) New specificities in Australia antigen positive sera distinct from the Le Bouvier determinants. Journal of Immunology, 109, 1017

Magnius, L.O., Lindholm, A., Lundin, P. \& Iwarson, S (1975) A new antigen-antibody system : clinical significance in long-term carriers of hepatitis B surface antigen. Journal of the American Medical Association, 231, 356.

Mascoli, C.C., ItTensohn, O.L., Villarejos, V.M., Arguedas, J.A., Provost, P.J. \& Hilleman, M.R. (1975) Recovery of hepatitis agents in the marmoset from human cases occurring in Costa Rica. Proceedings of the Societ. for Experimental Biology and Medicine, 142, 276.

Maupas, P., Goudeau, A., Coursaget, P., Drucker, J. \& BAGROS, P. (1976) Immunisation against hepatitis B in man. Lancet, ii, 1367.

Mayumi, M., Окосні, K. \& Nishioka, K. (1971) Detection of Australia antigen by means of immune adherence hemagglutination test. Vox saguinis, 20, 178.

Miller, W.J., Provost, P.J., McAleer, W.J., Ittensohn, O.L., Villarejos, V.M. \& Hilleman, M.R. (1975) Specific immune adherence assay for human hepatitis A antibody. Application to diagnostic and epidemiologic investigations. Proceedings of the Society for Experimental Biology and Medicine, 149, 254.

Moritsugu, Y., Dienstag, J.L., Valdesuso, J., Wong, D.C., Wagner, J., Routenberg, J.A. \& Purcell, R.H. (1976) Purification of hepatitis A antigen from feces and detection of antigen and antibody by immune adherence hemagglutination. Infection and Immunity, 13, 898.

Moritsugu, Y., Gold, J.W.M., Wagner, J., Dodd, R.Y. \& Purcell, R.H. (1975) Hepatitis B core antigen: detection of antibody by radioimmunoprecipitation. Journal of Immunology, 114, 1792.

MosLey, J.W. (1975) The epidemiology of viral hepatitis: ap overview. American Journal of the Medical Sciences, 270s 253.

Mosley, J.W., Redeker, A.G., Feinstone, S.M. \& Purcell R.H. (1977) Etiologic studies of multiple attacks of acute viral hepatitis. New England Journal of Medicine, 296, 75.

Neefe, J.R., Gellis, S.S. \& Stokes, J., JR (1946) Homologous serum hepatitis and infectious (epidemic) hepatitis: studies in volunteers bearing on immunological and other characteristics of the etiological agents. American Journal of Medicine, 1, 3.

Nielsen, J.O., Dietrichson, O. \& Juhl, E. (1974) Incidence and meaning of the ' $e$ ' determinant among hepatitis-Bantigen positive patients with acute and chronic liver diseases. Lancet, ii, 913.

Nordenfelt, E. \& KJellen, L. (1975) Dane particles, DNA polymerase, and e-antigen in two different categories of hepatitis B antigen carriers. Intervirology, 5, 225.

Paul, J.R., Havens, W.P., JR, Sabin, A.B. \& Philip, C.B. (1945) Transmission experiments in serum jaundice and infectious hepatitis. Journal of the American Medical Association, 128, 911 .

Prince, A.M. (1968) An antigen detected in the blood during the incubation period of serum hepatitis. Proceedings of the National Academy of Sciences, 60, 814.

Prince, A.M., Szmuness, W., Mann, M.K., Vyas, G.N., Grady, G.F., Shapiro, F.L., Suki, W.N., Friedman, E.A. \& Stenzel, K.H. (1975) Hepatitis B 'immune' globulin: effectiveness in prevention of dialysis-associated hepatitis. New England Journal of Medicine, 293, 1063.

Provost, P.J., ItTensohn, O.L., Villarejos, V.M., Arguedas, J.A. \& Hilleman, M.R. (1973) Etiologic relationship of marmoset-propagated CR326 hepatitis A virus to hepatitis in man. Proceedings of the Society for Experimental Biology and Medicine, 142, 1257.

Provost, P.J., ItTensohn, O.L., Villarejos, V.M. \& Hilleman, M.R. (1975a) A specific complement-fixation test for human hepatitis A employing CR326 virus antigen. 
Diagnosis and epidemiology. Proceedings of the Society for Experimental Biology and Medicine, 148, 962.

Provost, P.J., Wolanski, B.S., Miller, W.J., Ittensohn, O.L., McAleer, W.J. \& Hilleman, M.R. (1975b) Physical, chemical and morphologic dimensions of human hepatitis A virus strain CR326. Proceedings of the Society for Experimental Biology and Medicine, 148, 532.

Purcell, R.H., Dienstag, J.L., Feinstone, S.M. \& KaPIKIAN, A.Z. (1975) Relationship of hepatitis A antigen to viral hepatitis. American Journal of the Medical Sciences, 270, 61 .

Purcell, R.H. \& Gerin, J.L. (1975) Hepatitis B subunit vaccine: a preliminary report of safety and efficacy tests in chimpanzees. American Journal of the Medical Sciences, 270, 395.

Purcell, R.H., Gerin, J.L., Almeida, J.D. \& Holland, P.V. (1974) Radioimmunoassay for detection of the core of the Dane particle and antibody to it. Intervirology, 2, 231.

Purcell, R.H., Gerin, J.L., London, W.T., Wagner, J., McAuliffe, V.J., Popper, H., Palmer, A.E., Lvovsky, E., Kaplan, P.M., Wong, D.C. \& Levy, H.B. (1976a) Modification of chronic hepatitis-B virus infection in chimpanzees by administration of an interferon inducer. Lancel, ii, 757.

Purcell, R.H., Wong, D.C., Moritsugu, Y., Dienstag, J.L., Routenberg, J.A., \& Boggs, J.D. (1976b) A microtiter solid-phase radioimmunoassay for hepatitis A antigen and antibody. Journal of Immunology, 116, 349.

REDEKER, A.G. (1975) Viral hepatitis: clinical aspects. American Journal of the Medical Sciences, 270, 9.

Redeker, A.G., Mostey, J.W., Gocke, D.J., MCKee, A.P. \& Pollack, W. (1975) Hepatitis B immune globulin as a prophylactic measure for spouses exposed to acute type B hepatitis. New England Journal of Medicine, 293, 1055.

Robinson, W.S., Clayton, D.A. \& Greenman, R.L. (1974) DNA of a human hepatitis B virus candidate. Journal of Virology, 14, 384.

Robinson, W.S. \& GReEnMan, R.L. (1974) DNA polymerase in the core of the human hepatitis B virus candidate. Journal of Virology, 13, 1231.

Schulman, A.N., Dienstag, J.L., Jackson, D.R., Hoofnagle, J.H., Gerety, R.J., Purcell, R.H. \& Barker, L.F. (1976) Hepatitis A antigen particles in chimpanzee liver, bile and stool. Journal of Infectious Diseases, 134, 80.

SeefF, L.B., Zimmerman, H.J., Wright, E.C., Felsher, B.F., Finkelstein, J.D., Garcia-Pont, P., Greenlee, H.B., Dietz, A.A., Hamilton, J., Koff, R.S., Leevy, C.M., Kiernan, T., Tamburro, C.H., Schiff, E.R., Vlahcevic, Z., Zemel, R., Zimmon, D.S. \& NATH, N. (1975) Efficacy of hepatitis B immune serum globulin after accidental exposure. Lancet, ii, 939.

Sergent, J.S., Lockshin, M.D., Christian, C.L. \& Gocke, D.J. (1976) Vasculitis with hepatitis B antigenemia: longterm observations in nine patients. Medicine. Baltimore, $55,1$.

ShiH, J.W.-K. \& Gerin, J.L. (1975) Immunochemistry of hepatitis $B$ surface antigen $\left(\mathrm{HB}_{\mathbf{s}} \mathrm{Ag}\right)$. Preparation and characterization of antibodies to constituent polypeptides. Journal of Immunology, 115, 634.

Surgenor, D. MacN., Chalmers, T.C., Conrad, M.E., Friedewald, W.T., Grady, G.F., Hamilton, M., Mosley, J.W., Prince, A.M. \& Stengle, J.M. (1975) Clinical trials of hepatitis B immune globulin: development of policies and materials for the 1972-1975 studies sponsored by the National Heart and Lung Institute. New England Journal of Medicine, 293, 1060.

Szmuness, W. (1975) Recent advances in the study of the epidemiology of hepatitis B. American Journal of Pathology, 81, 629.

Szmuness, W., Dienstag, J.L., Purcell, R.H., Harley, E.J., Stevens, C.E. \& Wong, D.C. (1976) Distribution of antibody to hepatitis A antigen in urban adult populations. New England Journal of Medicine, 295, 755.

Takahashi, K., Imai, M., Tsuda, F., TaKahashi, T., MiyaKawa, Y. \& Mayumi, M. (1976) Association of Dane particles with $\mathrm{e}$ antigen in the serum of asymptomatic carriers of hepatitis B surface antigen. Journal of Immuno$\log y, 117,102$.

Tsuda, F., Takahashi, T., Takahashi, K., Miyakawa, Y. \& MaYumi, M. (1975) Determination of antibody to hepatitis B core antigen by means of immune adherence hemagglutination. Journal of Immunology, 115, 834.

Villarejos, V.M., Provost, P.J., Ittensohn, O.L., Mclean, A.A. \& Hilleman, M.R. (1976) Seroepidemiologic in vestigations of human hepatitis caused by $A, B$, and ace possible third virus. Proceedings of the Society for Experi-D mental Biology and Medicine, 152, 524.

Villarejos, V.M., Visona, K.A., Eduarte A., C.A., Provost, P.J. \& Hilleman, M.R. (1975) Evidence for viral hepatitis other than type A or type B among persons in Costa Rica. New England Journal of Medicine, 293, 1350.

Voegt, H. (1942) Zur Ätiologie der Hepatitis Epidemica. Münchener medizinische Wochenschrift, 89, 76.

Vyas, G.N. \& Shulman, N.R. (1970) Hemagglutination assay for antigen and antibody associated with viral hepatitis. Science, 170, 332.

Williams, A.O. (1975) Hepatitis B surface antigen and liver cell carcinoma. American Journal of the Medical Sciences, 270, 53. 